\title{
Indonesia's Development Policy to Increase Prosperity of the People in the Border Area
}

\author{
Sonny Sudiar \\ Mulawarman University, Samarinda \\ sony.azzam.sudiar@gmail.com
}

\author{
Bambang Irawan \\ Mulawarman University, Samarinda \\ bambangirawan2011@gmail.com
}

\begin{abstract}
The main issue of this paper highlights the development policy and prosperity of the people in the border area. The border area has always been the sexiest issues to discuss, as it is identical as a lagging and isolated area. The collaboration between the government and local communities to overcome those problems is needed. In this case, development policy becomes the key role in order to increase the quality of social life especially for the local people. The notion of development has lost its significance due to the absence of ethics or moral dimension. Practically, the ethics make the development more meaningful for the entire human life and environment comprehensively. Development is a necessity that must be done by every single government to make progress and change for the better life of the citizens. Development also can be seen as a process of expanding prosperity of the social life.
\end{abstract}

Keywords: community development, border area, development policy

\section{INTRODUCTION}

Development is a necessity that must be done for reasons of progress and change for the better. This development becomes a process that should continuously be done by any government of a country to improve and enhance the quality of life in society. Furthermore, the study of development grows in more various ways and richer in terms of its research areas and focus as recently scholars of development stressed the importance of human security. Moreover, a different version of security studies emphasized on the overall wellness of individual/human rather than just mere statistics of development [1]-[2].

As well as Indonesia, the significant reason to increase the development that does not only improve the wellbeing of the society but also to protect them in this country is to liberate Indonesia from underdevelopment problem that continuously haunts the country. It is widely known that the problem of underdevelopment is a national problem, but the border areas suffer more compare to the other regions in Indonesia. There are lack of basic infrastructures such as health service, education, communication, and many more [3]. Based on the aforementioned explanations, the most urgent agenda is to improve the development in the border regions of Indonesia.
Border area is defined as an area that geographically and demographically adjoins with the borders of a country. Scholars exploring the study of international border have developed extensive literatures on the topics which range from the issue of state's sovereignty on the border area [4], the relations between border and international cooperation [5], the construction of border both in physical infrastructure and in intangible perception of people's mind [6]-[7]

One of Indonesia's most worrying borders is Indonesia-Malaysia border in North Kalimantan. The problems ranged from high political issues such as dispute borderlands, damage or missing demarcation pillars to social and economic issues such as undeveloped region, low or non-existing of basic infrastructures, low accessibility, backwards and so on.

Indonesian government were fully aware of the problem, and had issued several policy designed to improve the wellbeing of the society living in the border area. Nevertheless, the life of "the border people" cannot be separated with their old problems as described before. Therefore, the purpose of this paper is to examine the main problem in developing the border area especially in North Kalimantan. Besides, this paper also explains why the border area seems to be left behind, in terms of its development. In addition, numerous policies are designed to overcome the problems.

To sum up, this paper will be divided into three sections, namely: numerous policies and the outcomes related to border area, description of real condition of the society in border area, and explanation on community development as the strategy to increase prosperity in border area.

First, we discuss about numerous policies issued by the government to manage the border area, especially in North Kalimantan and the outcomes of those policies. Second, we describe the real condition of the society living in the border area, and the third, we try to explain the community development as the strategy to increase prosperity in the border area.

\section{Development Policy in North Kalimantan Border Area \\ There are twelve provinces in Indonesia that have international borders. However, there are only four areas that have land borders with other countries, namely: West Kalimantan Province, East Kalimantan Province, East Nusa Tenggara Province, and Papua [8].}


Each of these border areas has socio-cultural and economic characteristics that are relatively different from one another. On the other hand, there is a similar phenomenon: an existence of a direct and intensive interaction between Indonesian citizens with citizens of neighboring states, which influence socio-cultural relations in both of traditional and modern economic activities. One of Indonesia's border regions that has the highest degree of activity and trade-economic interaction is the border of North Kalimantan Province and the State of Sabah. This can be seen from a long traditional trade that has occurred between people on the border of Indonesia and Malaysia.

As stated before, Jakarta had issued several efforts to manage and overcome complex problem in the border area, one of it was to issue numerous policies related to the management of border area and society. The regulations were started with Presidential Decree No.44 on Agency for the Implementation and Control of Development in Kalimantan Border Area (Badan Pengendali Pelaksanaan Pembangunan Wilayah Perbatasan di Kalimantan, BP3WPK) in 1994, Presidential Decree No 55 on Development Council on Eastern Part of Indonesia (Dewan Pengembangan Kawasan Timur Indonesia) in 2001, and Presidential Decree No.44/2002 in 2002.

Then, a stricter and assertive law was approved in President Susilo Bambang Yudhoyono's presidency. The Law No.43 2008 on National Territory clearly mentions that the border as integral part of Indonesia and it requires specific agency to manage them. It was then manifested in Presidential Decree No.12 Year 2010 on National Border Management Agency (Badan Nasional Pengelola Perbatasan). The agency was regarded as the culmination of years after years in finding the right policies to overcome the problems in border areas.

The creation of National Border Management Agency was expected to solve the problem of overlapping policies that arise from multi-level of governance concerning the management of border area. It is assumed that so many regulations made the management of the border area firm in terms of its legality and formal regulations. However, the problems arise from that was when each of those regulations directs the management of border area to different institutions with their different policies. The ineffectiveness became the main reason why the management of Indonesian border area was incapable to respond the challenges and also threats such as: illegal logging, illicit trade, people smuggling, and conflicts of demarcation pole.

Focusing on synchronizing and harmonizing the overlapping policies that seemingly stemmed from institutional ego, National Border Management Agency leave the technical implementation of border policies to each of its members such as: the ministry, local governments and other related institutions. Nonetheless, based on the regulation, those policies of its member should be guided by the grand design and blueprint of border development policies made by National Border
Management Agency. Two regulations in which National Border Management Agency was based on, Law No.43/2008 and Presidential Decree No.12/2010 gives BNPP limited authority that contain of planning, coordinating and evaluating. In other words, National Border Management Agency does not have any authority to directly implement the development programs. Then, if it can be implemented, the programs are only limited to small budget program and the main large scale program still reside within the domain of related institution. For example, the program of road building and other basic infrastructures were carried out by Ministry of Public Works (Kementerian Pekerjaan Umum).

For some people, the limited authority of National Border Management Agency correlates with its limited impact on border development. One of the staff in the agency said that her institution cannot perform in maximal involvement due to its limited authority. As a person who involves directly on issues regarding territorial demarcation on the sea and air, she admitted that the leading sector or the leading institutions on the negotiating process and execution of the agreement was not National Border Management Agency but two institutions who usually deals with the problem: the Ministry of Foreign Affairs and Indonesian National Army. In this case, National Border Management Agency was only involved as observer and did not have much opportunity to speak in the forum especially when the forum discussed about high political issues such as territorial demarcation.

After all it can be said that National Border Management Agency, which is the national level institution cannot involve maximally in the implementation of the development program. It indicated that the similar thing would happen on the lower level. Needless to say, even after so many policies and regulations, the life and also the conditions of people living in the border area remains the same. There are no significant improvements regarding their quality of life. To have more insight on the conditions of the border area and its people in North Kalimantan, the next section will discuss the topic in more accurate ways.

\section{The Condition of Border Area in North Kalimantan}

There are two Regency in North Kalimantan that shared borders with Malaysia; they are the Regency of Malinau and Nunukan. Each regency contains of several districts. In Nunukan Regency, there are eight districts, namely: Districts of Nunukan, South Nunukan, Sebuku, Krayan, South Krayan, Sebatik, West Sebatik and Lumbis. Malinau Regency contains of five districts, namely: Kayan Hulu, Kayan Hilir, South Kayan, Pujungan, and Bahau Hulu. Generally, the main issues in border management in both regencies varied from political issue, such as obscure borderline to transportation access into the zone.

This description starts from Nunukan Regency in Lumbis District, Indonesia and Malaysia borderline stretch to $200 \mathrm{kms}$ with difficult geographical access. In Lumbis, Indonesia and Malaysia have not agreed on 
demarcation line between them, and it led to make the area politically prone of conflict. Similar situation also happened in Sebuku District where several Outstanding Border Problem (OBP) are needed to be solved.

In Krayan and South Krayan District, the main problem is low accessibility due to difficult geographical landscape. To reach Krayan there is only one transportation mode, by an hour flight from Nunukan District. It makes Kayan and South Kayan isolated from other districts in Nunukan Regency. Low accessibility also make people from both districts are fully dependent on Malaysian supply. Many basic needs, ranging from food to building materials are supplied from Malaysia.

Meanwhile, in Sebatik and West Sebatik, the conditions are slightly different, where both districts in Sebatik Island enjoy relatively better accessibility and economic activities compare to the other four districts in Nunukan Regency. People on Sebatik and West Sebatik District get the benefit from their interaction with Tawau people where majority of Tawau's needs are supplied by Sebatik and West Sebatik District. This condition triggers economic boost in both districts. More interestingly, that economic boost is driven from informal trade with little or no involvement of Indonesian government.

In Malinau Regency, the conditions are similar with those of in the districts in Nunukan Regency. In Kayan Hilir and South Kayan District, the main problem is low accessibility because of difficult geographical setting that makes cross-border activities hard to do.

In contrast with previously mentioned two districts, Kayan Hulu district has cross-border activities although they are not as frequent as it happens in Nunukan Regency. The cross-border activities usually facilitated by traditional institution such as the tribal authority. In other words, informal sector plays larger part in the interaction. There are two Cross-Border Posts (Pos Lintas Batas) in Kayan Hulu: Long Nawang-Long Busang Post and Long Nawang-Long Singut Post, but the difficult ease of access to get to the places makes people create informal path to cross the border.

In Bahau Hulu and Pujungan District, the issues are more or less the same with other districts. In those districts, Kayan Menatarang National Park, a conservation area, is situated. In turn, it makes the border issues more complicated.

\section{Community Development as the Strategy to Improve People's Prosperity in the Border Area}

Community development is a process or a way of doing things. It can bring people together; help people to identify the problems and their needs; help people to discover the resources that they had; promote knowledge, skills, confidence and the capacity to act together; strengthen organization and leadership within communities; strengthen contacts between communities. The main keyword of this comprehension is that community get involved in development. Border area community development is a process conducted by community members. It is a process where local people can not only create more job, income and infrastructure, but also help their community becomes fundamentally have better capability to manage change (Cavaye, n.d.).

The concrete benefit of community development, such as employment and infrastructure, come through local people changing attitudes, mobilizing existing skills, improving networks, thinking differently about problems, and using community assets in new ways. Community development improves the situation of a community, not just economically, but also as a strong functioning community in itself. Community has five elements, such as: capitals-physical, financial, human, and social and environment. Those capitals can be used to improve the quality of their life. Border area community development builds those capitals. It goes through participation in their community that people rethink problems and expand contact and networks: building social capital. They learn new skills, building human capital. They develop new economic options, building physical and financial capital. They also can improve their environment.

Once people in border area are working together, it can help them to take action to address inequalities in power and participation, deal directly with issues they think are important, change the relationships between communities and public or private organizations, help public organizations to work in more open and inclusive ways, promote increased local democracy, and the last, participation and involvement in public affairs.

\section{CONCLUSION}

The issue of development in the border area has become a very serious concern at the national level. For the government of the Republic of Indonesia, development in the border area is closely related to the mission of national development, especially to ensure the integrity and sovereignty of the territory, defense, and national security in improving public welfare. In order to realize these interests, the strategy which is required by the government of the Republic of Indonesia is to involve community in border area to promote their capacity in development process.

\section{REFERENCES}

[1] Ackleson, J. Directions in border security research. Social Science Journal, 40(4), 573-581. https://doi.org/10.1016/S0362-3319(03)00069 7.2003 .

[2] Ackleson, J. Constructing security on the U.S.Mexico border. Political Geography, 24(2), 165184. https://doi.org/10.1016/j.polgeo.2004.09.017. 2005.

[3] Ajdari, B., \& Asgharpour, S. E. Human security and development, emphasizing on sustainable Development. Procedia - Social and Behavioral Sciences, 19 , 41-46. https://doi.org/10.1016/j.sbspro.2011.05.105. 2011. 
[4] Aker, J. C., Klein, M. W., O’Connell, S. A., \& Yang, M. Borders, ethnicity and trade. Journal of Development Economics, 107, 1-16. https://doi.org/10.1016/j.jdeveco.2013.10.004. 2014.

[5] Baird, I. G., \& Cansong, L. (2017). Variegated borderlands governance in Dehong Dai-Jingpo Autonomous Prefecture along the China-Myanmar border. Geoforum, 85(July), 214-224. https://doi.org/10.1016/j.geoforum.2017.07.026. 2017.

[6] Bochaton, A. (2014). Cross-border mobility and social networks: Laotians seeking medical treatment along the Thai border. Social Science and Medicine, 124, 364373. https://doi.org/10.1016/j.socscimed. 2014.10.022. 2014

[7] Busumtwi-Sam, J. (2008). Contextualizing human security: A "deprivation-vulnerability" approach. Policy and Society, 27(1), 1528. https://doi.org/10.1016/j.polsoc.2008.07.002. 2008.

[8] Castanho, R. A., Vulevic, A., Cabezas Fernández, J., Fernández-Pozo, L., Naranjo Gómez, J. M., \& Loures, L. C. Accessibility and connectivity Movement between cities, as a critical factor to achieve success on cross-border cooperation (CBC) projects. A European analysis. Sustainable Cities and Society, 32(March), 181-190. https://doi.org/10.1016/j.scs.2017.03.026. 2017.

[9] Chaderopa, C. Crossborder cooperation in transboundary conservation-development initiatives in southern Africa: The role of borders of the mind. Tourism Management, 39, 50-61. https://doi.org/10.1016/j.tourman.2013.04.003. 2013.

[10] Cons, J., \& Sanyal, R. Geographies at the margins: Borders in South Asia-an introduction. Political Geography,35,513.https://doi.org/10.1016/j.polgeo.2 013.06.001. 2013.

[11] Hayakawa, K. Domestic and international border effects: The cases of China and Japan. China Economic Review, 43(26285058), 118-126. https://doi.org/10.1016/j.chieco.2017.01.014. 2017.

[12] Jones, R., Johnson, C., Brown, W., Popescu, G., Pallister-Wilkins, P., Mountz, A., \& Gilbert, E. Interventions on the state of sovereignty at the border. Political Geography, 59, 1-10. https://doi.org/10.1016/j.polgeo.2017.02.006. 2017.
[13] Kester, J. Energy security and human security in a Dutch gasquake context: A case of localized performative politics. Energy Research and Social Science,24,1220.https://doi.org/10.1016/j.erss.2016. 12.019. 2017.

[14] Koespramoedyo, D. Strategi dan Model Pengembangan Wilayah Perbatasan Kalimantan. Jakarta: National Development Planning Body of Indonesia (Bappenas). 2013.

[15] Lamb, V. "Where is the border?" Villagers, environmental consultants and the "work" of the Thai-Burma border. Political Geography, 40, 1-12. https: //doi.org/10.1016/j.polgeo.2014.02.001. 2014.

[16] Medeiros, E. Cross-border cooperation in inner Scandinavia: A territorial impact assessment. Environmental Impact Assessment Review, 62, 147157. https://doi.org/10.1016/j.eiar.2016.09.003. 2017.

[17] Opasanon, S., \& Kitthamkesorn, S. Border crossing design in light of the ASEAN Economic Community: Simulation based approach. Transport Policy, 48, 112. https: //doi.org/10.1016/j.tranpol.2016.02.009. 2016.

[18] Shibuya, K. (2016). Protecting human security: Proposals for the G7 Ise-Shima Summit in Japan. TheLancet,387(10033),21552162.https://doi.org/10. 1016/S0140-6736(16)30177-5.2016.

[19] Shneiderman, S. B. Himalayan border citizens: Sovere ignty and mobility in the Nepal-Tibetan Autonomous Region (TAR) of China border zone. Political Geography, 35, 25-36. https: //doi.org/10.1016/j.polgeo.2013.04.001. 2013.

[20] The Partnership for Governance Reform. Kebijakan Pengelolaan Kawasan Perbatasan Indonesia. Partnership Policy Paper No. 2/2011. Jakarta. Retrieved from http://www.kemitraan.or.id/policypaperno22011kebijakanpengelolaankawasanperbatasan. 2011. 